\title{
IDENTIFIKASI TANAMAN RAMBUTAN (NEPHELIUM LAPPACEUM L.) LOKAL KABUPATEN BENGKALIS BERDASARKAN KARAKTER MORFOLOGI
}

\section{Identification of Local Rambutan (Nephelium lappaceum L.) Plants in Bengkalis Regency Based on Morphological Characters}

\author{
Solihin $^{1}$, Aslim Rasyad ${ }^{2}$, Isnaini ${ }^{2}$ \\ ${ }^{1)}$ Mahasiswa Jurusan Agroteknologi, Fakultas Pertanian, Universitas Riau \\ ${ }^{2}$ Dosen Jurusan Agroteknologi, Fakultas Pertanian, Universitas Riau \\ Email: lihin0205@gmail.com/HP: 085282590360 \\ [Diterima: Desmber 2021; Disetujui: Desember 2021]
}

\begin{abstract}
Even though rambutan is originating from Indonesia, its variability tents to decrease due to farmer selection to plant marketable varieties. The objectives of this study are to determine the diversity of several morphological characteristics and to analyse the relationship among rambutan plants in Bengkalis Regency. Thirty-one plants were chosen by purposive sampling in five districts of the Bengkalis Regency. Every plant was identified its morphological characteristic, including leaves, flowers, fruit, and seed characteristics. In general, most leaves, flower, fruit, and seed characteristics had from low to moderate variability. Tree characteristics, including canopy type growth habits and leaves length had high variability. Cluster analysis indicated that thirty-one plants were divided into three groups, namely group one consisted of two plants, group two consisted of 11 plants, and group three consisted of 18 plants.
\end{abstract}

Keywords: Rambutan, Variability, Morphological Characteristic, Relationship.

\begin{abstract}
ABSTRAK
Walaupun tanaman rambutan berasal dari Indonesia, variabilitasnya sudah menurun karena petani lebih suka menananam variatas-variatas yang hasilnya mudah di pasarkan. Oleh sebab itu tujuan dari penelitian ini adalah untuk mengetahui variabilitas sifat-sifat morfologi dan untuk melihat hubungan kekerabatan antar tanaman-tanaman yang diamati di Kabupaten Bengkalis. Tiga puluh satu tanaman rambutan di pilih secara purposive random sampling di lima Kecamatan di Kabupaten Bengkalis. Setiap tanaman sampel diidentifikasi sifat-sifat morfologinya antara lain karakter pertumbuhan, daun, bunga, buah dan biji. Pada umumnya kakter-karakter daun, bunga, buah dan biji mempunyai keragaman yang rendah sampai sedang. Tiga karakter termasuk bentuk kanopy, klebiasaan pertumbuhan dan panjang daun mempunyai keragaman yang tinggi. Analisis cluster menunjukan bahwa 31 tanaman rambutan terbagi menjadi tiga kelompok yaitu kelompok satu, dua dan 3. Kelompok satu terdiri dari 2 tanaman, kelompok dua terdiri dari 11 tanamn dan kelompok tiga terdiri dari 18 tanaman.
\end{abstract}

Kata kunci: Rambutan, Keragaman, Karakter Morfologi, Hubungan Kekerabatan

\section{PENDAHULUAN}

Rambutan (Nephelium lappaceum L.) merupakan tanaman yang berasal dari Indonesia. Buah rambutan mempunyai ciri khas yaitu kulit buah yang berambut, rasa buah manis sampai asam, tekstur lembut dan halus sehinga banyak disukai oleh masyarakat sebagai makanan buah segar atau makan olahan dalam kaleng. Walaupun tanaman rambutan berasal dari Indonesia, variabilitasnya sudah menurun karena petani lebih suka menananam variatas-variatas yang hasilnya mudah di pasarkan, padahal Buah rambutan mempunyai andil besar terhadap perkonomian serta kesehatan manusia, karena buah rambutan mempunyai kandungan gizi yang cukup tinggi sebagai sumber vitamin $\mathrm{A}$, 
vitamin $\mathrm{C}$, vitamin $\mathrm{B} 6$, vitamin B12, kalsium, magnesium dan zat besi.

Kebun rambutan di Kabupaten Bengkalis cukup luas dan jenisnya pun cukup beragam. Seiring dengan berjalannya waktu banyak terjadi alih fungsi lahan kebun rambutan menjadi perkebunan sawit karet maupun pembangunan permukiman masyarakat, sehingga membuat kebun rambutan pun terus berkurang luasnya. Hal ini tentu akan mengakibatkan berkurangnya keragaman genetik dan jenis tanaman rambutan yang ada dan hilangnya sifat-sifat baik tertentu, selain itu juga akan mengakibatkan produksi buah rambutan akan semakin berkurang.

Penelitian yang berkaitan dengan keragaman rambutan di Kabupaten Bengkalis belum pernah dilakukan, padahal keragaman jenis sangat penting dilakukan untuk mengidentifikasi plasma nutfah rambutan, konservasi buah-buahan lokal dan bermanfaat dalam program pengembangan tanaman rambutan. Oleh karena itu perlu dilakukan kegiatan pengumpulan data mengenai jenis rambutan melalui kegiatan ekplorasi dan identifikasi tanaman rambutan yang ada di Kabupaten Bengkalis serta mengetahui keragaman dan analisis hubungan kekerabatannya.

Tujuan dari penelitian ini bertujuan untuk mengetahui keragaman karakter-karakter morfologi tanaman rambutan dan melihat hubungan kekerabatan antar tanaman rambutan yang ada di Kabupaten Bengkalis.

\section{METODE PENELITIAN}

Penelitian ini dilaksanakan secara eksplorasi di lima kecamatan di kabupaten bengkalis provinsi riau pada bulan AprilAgustus 2019. Tanaman sampel ditentukan dengan purposive sampling di setiap kecamatan sampel dengan menjelajahi daerahdaerah yang petaninya membudidayakan tanaman rambutan. Sebanyak 31 tanaman sampel dipilih dari lima kecamatan sampel dengan pertimbangan pertimbangan tanaman sampel adalah tanaman rambutan yang sudah menghasilkan buah dengan minimal umur sepuluh tahun. Tanaman sampel diberi identitas dengan nomor tanaman mulai dari TN1, TN2 sampai dengan TN31. Setiap tanaman sampel diamati beberapa karakter morfologi yaitu 4 karakter pertumbuhan, 10 karakter daun, 4 karakter bunga, 14 karakter buah dan 3 karakter biji. Pedoman pengamatan karakter-karakter morfologi pada tanaman rambutan berdasarkan buku panduan deskritor tanaman rambutan yang disusun IPGRI (2003).

Data hasil pengamatan dianalisi dengan keragamannya, standar deviasi dan koefisien keragaman memakai program Micrisoft Excel. Penentu kekerabatan antar tanaman untuk melihat nilai kemiripannya dilakukan dengan analisi cluter. Data-data ditransformasikan menjadi data biner dalam bentuk matriks. Dari matriks data biner, selanjutnya dihitung matriks kemiripan antar nomor aksesi tanaman yang diamati. Berdasarkan nilai kemiripan tersebut dibuat pengelompokan nomor-nomor aksesi tersebut dengan menggunakan program NTSYS-pc version 2.0.

\section{HASIL DAN PEMBAHASAN}

\section{Keragaman Karakter Morfologi Tanaman Rambutan.}

Keragaman karakter morfologi tanaman rambutan di Kabupaten Bengkalis ditampilkan dalam bentuk ragam dan koefisien keragaman (KK). Koefisien keragaman digunakan untuk menduga tingkat perbedaan antar spesies atau populasi pada karakter tertentu (Miswarti et al., 2017). Karakter morfologi yang diamati memiliki nilai koefisien keragaman (KK) rendah hingga tinggi, untuk melakukan pengelompokan nilai keragaman dapat dilihat dari nilai koefisien keragaman. Keragaman tidak ada/seragam (0\%), keragaman rendah $(0,1-25 \%)$, keragaman sedang $(25,1-50 \%)$ dan keragaman tinggi $(>50,1 \%)$ (Suratman et al., 2000).

\section{Karakter Pertumbuhan Rambutan}

Hasil analisa data pertumbuhan tanaman rambutan pada 31 tanaman rambutan asal Kabupaten Bengkalis menunjukan nilai keragaman karakter pertumbuhan yang diamati berkisar 0,76 hingga 2,12. Dari perhitungan koefisien keragaman (KK), nilai keragaman pada karakter kerapatan cabang dan pola percabangan termasuk memiliki keragaman sedang. Sedangkan karakter bentuk tajuk dan kebiasaan pertumbuhan memiliki keragaman tinggi. Keragaman karakter pertumbuhan tanaman rambutan asal Kabupaten Bengkalis dapat dilihat pada Tabel 1. 
Tabel 1. Data ragam dan koefisien keragaman karakter pertumbuhan 31 tanaman rambutan asal Kabupaten Bengkalis.

\begin{tabular}{lccc}
\hline \multicolumn{1}{c}{ Karakter Pertumbuhan } & Ragam & KK $(\%)$ & Keterangan \\
\hline Bentuk tajuk & 1,84 & 51,23 & Tinggi \\
Kebiasaan pertumbuhan & 1,13 & 53,23 & Tinggi \\
Kerapatan cabang & 2,12 & 26,43 & Sedang \\
Pola percabangan & 0,76 & 39,78 & Sedang \\
\hline
\end{tabular}

Tanaman rambutan asal Kabupaten Bengkalis memiliki bentuk tajuk oblong, piramida, semisirkuler dan spherical. Bentuk tajuk tanaman rambutan asal Kabupaten Bengkalis didominasi oleh bentuk spherical sebanyak 14 tanaman. Kebiasaan pertumbuhan tanaman rambutan yang ditemui terdapat empat tipe yaitu kebiasaan tumbuh tegak, setengah tegak, menyebar dan terkulai. Pertumbuhan tanaman rambutan didominasi dengan kebiasaan pertumbuhan tegak sebanyak 15 tanaman. Kerapatan percabangan tanaman rambutan memiliki tingkat kerapan jarang, sedang dan rapat. Kerapatan percabangan tanaman rambutan didominasi dengan tingkat kerapatan sedang dengan 15 tanaman, sedangkan Pola percabangan tanaman rambutan memiliki tiga tipe yaitu pola tegak lurus, horizontal dan tidak beraturan. Pola percabangan rambutan didominasi oleh pola tidak beraturan 15 tanaman.

Karakter pertumbuhan tanaman rambutan memiliki bentuk yang bervariasi, hal ini dapat disebabkan karena faktor genetik dan lingkungan. Menurut Coleman et al. (1994) variasi fenotip selain dipengaruhi oleh faktor genetik, juga diinduksi oleh lingkungan. Adanya variasi bentuk kanopi dapat disebabkan oleh ruang yang membuat kanopi tidak simetris karena lebar kanopi sulit bertambah akibat persaingan dengan kanopi pohon di sekitarnya (Sandono et al,. 2008).

\section{Karakter Daun Tanaman Rambutan}

Hasil analisa data karakter daun tanaman rambutan pada 31 tanaman rambutan asal Kabupaten Bengkalis menunjukan nilai keragaman karakter daun tanaman rambutan berkisar 0,03 hingga 1,05. Dari perhitungan koefisien keragaman (KK), nilai keragaman pada karakter panjang daun termasuk memiliki keragaman tinggi. Pada Karakter jumlah daun pertanaman, panjang tulang daun, bentuk apex tulang daun, bentuk pangkal daun dan permukaan daun memiliki keragaman sedang. Sedangkan karakter warna daun, bentuk tulang daun,dan tepi daun memiliki keragaman rendah. Keragaman karakter daun tanaman rambutan asal Kabupaten Bengkalis dapat dilihat pada Tabel 2.

Tabel 3. Data ragam dan koefisien keragaman karakter daun 31 tanaman rambutan asal Kabupaten Bengkalis

\begin{tabular}{lccc}
\hline \multicolumn{1}{c}{ Karakter Daun } & Ragam & KK $(\%)$ & keterangan \\
\hline Warna Daun & 0,03 & 06,05 & Rendah \\
Jumlah Daun & 1,05 & 39,74 & Sedang \\
Panjang Tangkai Daun & 0,89 & 45,00 & Sedang \\
Panjang Daun & 0,87 & 50,82 & Tinggi \\
Panjang Tulang Daun & 0,63 & 43,87 & Sedang \\
Bentuk Tulang Daun & 0,20 & 16,22 & Rendah \\
Bentuk Apex Tulang Daun & 0,43 & 28,10 & Sedang \\
Bentuk Pangkal Daun & 0,71 & 37,96 & Sedang \\
Tepi Daun & 0,13 & 12,24 & Rendah \\
Permukaan Daun & 0,25 & 35,34 & Sedang \\
\hline
\end{tabular}

Tanaman rambutan asal Kabupaten Bengkalis memiliki warna daun hijau terang, hijau dan hijau gelap. Warna daun tanaman rambutan di Kabupaten Bengkalis didominasi dengan warna hijau gelap sebanyak 30 tanaman. Pengamatan karakter jumlah daun pertanaman rambutan dijumpai empat tipe

yaitu sedikit, sedang, banyak dan sangat banyak. Jumlah daun per tanaman rambutan di Kabupaten Bengkalis didominasi oleh tipe banyak dengan 12 tanaman, sedangkan 
pengamatan panjang tangkai daun tanaman rambutan terdapat empat tipe yang dijumpai yaitu pendek, sedang, panjang dan sangat panjang. Panjang tangkai daun tanaman rambutan didominsasi oleh tipe panjang dengan 12 tanaman.

Pengamatan panjang daun tanaman rambutan terdapat empat tipe yaitu pendek, sedang, panjang dan sangat panjang. Panjang daun tanaman rambutan di Kabupaten Bengkalis didominasi oleh tipe pendek 11 tanaman. Pengamatan panjang tulang daun tanaman rambutan terdapat empat tipe yaitu pendek, sedang, panjang dan sangat panjang. Panjang tulang daun tanaman rambutan di Kabupaten Bengkalis didominasi oleh tipe pendek dengan 14 tanaman, Pengamatan bentuk tulang daun tanaman rambutan terdapat 3 karakter yang diamati yaitu obovate, elliptic dan lacollate. Bentuk tulang daun tanaman rambutan didominasi oleh bentuk lacollate dengan 22 tanaman. Sedangkan pada pengamatan bentuk apex tulang daun tanaman rambutan di Kabupaten Bengkalis terdapat tiga karakter yang di amati yaitu acute, acuminate dan abtuse. Bentuk apex tulang daun tanaman rambutan didominasi oleh bentuk acuminate dengan 15 tanaman.

Pengamatan bentuk pangkal daun tanaman rambutan di Kabupaten Bengkalis terdapat tiga bentuk yaitu acute, caneate dan abtuse. Bentuk pangkal daun di Kabupaten Bengkalis di dominasi oleh bentuk abtuse sebanyak 14 tanaman, Pada pengamatan bentuk tepi daun tanaman rambutan di Kabupaten Bengkalis terdapat beberapa bentuk yaitu penuh, bergelombang, tidak teratur dan keriting. Bentuk tepi daun tanaman rambutan di Kabupaten Bengkalis didominasi dengan bentuk tidak teratur sebanyak 30 tanaman. sedangkan pengamatan permukaan daun rambutan di Kabupaten Bengkalis terdapat dua karakter yaitu halus dan kasar. Permukaan daun tanaman rambutan di Kabupaten Bengkalis didominasi oleh tipe halus sebanyak 17 tanaman.

\section{Karakter Musim Berbunga Tanaman Rambutan}

Hasil analisa data pada tanaman rambutan di Kabupaten Bengkalis menunjukan nilai keragaman karakter musim berbunga berkisar 0,08 hingga 0,94. Dari perhitungan keragaman (KK), nilai keragaman pada karakter musim berbunga memiliki keragaman rendah. Sedangkan karakter posisi bunga, warna bunga dan bentuk malai memiliki keragaman sedang. Keragaman karakter bunga tanaman rambutan asal Kabupaten Bengkalis dapat dilihat pada Tabel 3.

Tabel 3. Data ragam dan koefisien keragaman karakter musim pembungaan tanaman rambutan asal Kabupaten Bengkalis

\begin{tabular}{lccc}
\hline \multicolumn{1}{c}{ Karakter Bunga } & Ragam & KK $(\%)$ & Keterangan \\
\hline Musim berbunga & 0,25 & 19,23 & Rendah \\
Posisi bunga & 0,32 & 41,81 & Sedang \\
Warna bunga & 0,08 & 25,64 & Sedang \\
Bentuk malai & 0,94 & 43,28 & Sedang \\
\hline \multicolumn{2}{c}{ Tanaman rambutan asal Kabupaten } & 23 tanaman, sedangkan pengamatan bentuk \\
Bengkalis memiliki tiga tipe musim berbunga & malai bunga tanaman rambutan terdapat tiga
\end{tabular}

yaitu cepat, sedang dan lambat. Musim berbunga tanaman rambutan di Kabupaten Bengkalis didominasi oleh musim berbunga lambat sebanyak 16 tanaman. Pengamatan posisi malai tanaman rambutan memiliki tiga tipe yaitu terminal, diketiak dan terminal dan ketiak. Posisi malai tanaman rambutan asal Kabupaten Bengkalis didominasi oleh terminal sebanyak 15 tanaman. Pengamatan tanaman rambutan asal Kabupaten Bengkalis pada warna bunga tanaman rambutan terdapat dua tipe yaitu hijau muda dan hujau. Warna bunga tanaman rambutan di Kabupaten Bengkalis didominasi oleh warna hijau muda sebanyak bentuk yaitu piramida, kerucut dan otriangular. Bentuk bunga tanaman rambutan asal Kabupaten Bengkalis didominasi oleh bentuk obtiangular sebanyak 15 tanaman.

\section{Karakter Buah Tanaman Rambutan}

Hasil analisa data pada 31 tanaman rambutan di Kabupaten Bengkalis menunjukan nilai keragaman karakter buah tanaman rambutan berkisar 0,16 hingga 1,2. Dari perhitungan koefisien keragaman (KK), nilai keragaman pada karakter warna aril, rasa aril dan kandungan air aril memiliki keragaman rendah. Sedangkan karakter kebiasaan tumbuh 
buah panjang tangkai buah, jumlah buah pertandan, bentuk, panjang buah, diameter buah, berat buah, ketebalan kulit buah, warna kulit buah, berat kulit buah, Keseragaman warna kulit buah, panjang rambut kulit buah, ketebalan aril, tekstur aril dan padatan terlarut total. Keragaman karakter buah tanaman rambutan asal Kabupaten Bengkalis dapat dilihat pada Tabel 4.

Tabel 4. Data ragam dan koefisien keragaman karakter buah 31 tanaman rambutan asal Kabupaten Bengkalis.

\begin{tabular}{lccc}
\hline \multicolumn{1}{c}{ Karakter buah } & Ragam & Kk $(\%)$ & Keterangan \\
\hline Kebiasaan tumbuh buah & 0,79 & 35,82 & Sedang \\
Panjang tangkai buah & 1,19 & 42,79 & Sedang \\
Jumlah buah pertandan & 0,64 & 33,88 & Sedang \\
Bentuk buah & 0,16 & 33,65 & Sedang \\
Panjang buah & 0,69 & 35,83 & Sedang \\
Diameter buah & 0,76 & 37,51 & Sedang \\
Berat buah & 0,77 & 37,26 & Sedang \\
Ketebalan kulit buah & 0,78 & 36,62 & Sedang \\
Warna kulit buah & 1,20 & 26,90 & Sedang \\
Berat kulit buah & 0,86 & 47,98 & Sedang \\
Keseragaman warna kulit buah & 0,24 & 35,90 & Sedang \\
Panjang rambut kulit buah & 0,99 & 39,03 & Sedang \\
Warna aril & 0,00 & 00,00 & Rendah \\
Ketebalan aril & 0,56 & 44,58 & Sedang \\
Tekstur aril & 0,95 & 45,62 & Sedang \\
Padatan terlarut total & 1,09 & 47,70 & Sedang \\
Rasa aril & 0,41 & 19,53 & Rendah \\
Kandungan air aril & 0,06 & 12,10 & Rendah \\
\hline
\end{tabular}

Tanaman rambutan asal Kabupaten Bengkalis memiliki tiga tipe kebiasaan tumbuh buah yaitu setahun sekali, dua tahun sekali, tidak beraturan. Kebiasaan tumbuh buah tanaman rambutan asal Kabupaten Bengkalis didominasi oleh tidak beraturan sebanyak 23 tanaman. Pengamatan panjang tangkai buah terdapat empat tipe yaitu pendek, sedang, panjang, sangat panjang. Panjang tangkai buah tanaman rambutan di Kabupaten Bengkalis didominasi oleh tipe panjang 9 tanaman. sedangkan pengamatan jumlah buah per tandan terdapat empat tipe yaitu sedikit, sedang, banyak dan sangat banyak. Jumlah buah pertandan pada tanaman rambutan di Kabupaten Bengkalis didominasi oleh tipe sedang 13 tanaman.

Pengamatan tanaman rambutan di Kabupaten Bengkalis pada bentuk buah terdapat tiga karakter yaitu bundar, bujur telur dan bujur. Bentuk buah tanaman rambutan di Kabupaten Bengkalis didominasi oleh bentuk bundar 25 tanaman. Pengamatan panjang buah rambutan terdapat empat tipe yaitu pendek, sedang, panjang dan sangat panjang. Panjang buah rambutan di Kabupaten Bengkalis didominasi oleh tipe sedang 13 tanaman, sedangkan pada diameter buah tanaman rambutan terdapat empat tipe yang diamati yaitu kecil, sedang, besar dan sangat besar. Diameter buah rambutan di Kabupaten

Bengkalis didominasi tipe besar sebanyak 15 tanaman.

Tanaman rambutan yang diamati di kabupaten bengkalis pada berat buah rambutan memiliki empat tipe yaitu, ringan, sedang, berat dan sangat berat. Berat buah rambutan di kabupaten bengkalis didominasi tipe sedang 16 tanaman. Pengamatan ketebalan kulit buah rambutan di Kabupaten Bengkalis terdapat empat tipe yaitu tipis, sedang, tebal dan sangat tebal. Ketebalan kulit buah tanaman rambutan di kabupaten bengkalis didominasi tipe sedang sebanyak 13 tanaman. Pengamatan warna kulit buah rambutan di Kabupaten Bengkalis terdapat tujuh tipe yaitu hijau, kuning, kuning kemerahan, orange, orange kemerahan, merah dan merah gelap. Warna kulit buah rambutan di Kabupaten Bengkalis didominasi tipe orange sebanyak 12 . Kulit tebal pada buahbuahan berhubungan erat dengan umur simpan buah tersebut. Buah yang berkulit tebal biasanya mempunyai umur simpan yang lebih lama dibandingkan dengan berkulit tipis (Antarlina, 2009).

Pengamatan tanaman rambutan asal Kabupaten Bengkalis pada berat kulit buah terdapat empat tipe yaitu tipis, sedang, tebal 
dan sangat tebal. Berat kulit buah rambutan yang terdapat di Kabupaten Bengkalis didominasi oleh karakter tipis sebanyak 12 tanaman. Keseragaman kulit buah rambutan yang diamati terdapat dua tipe yaitu tidak seragam dan seragam. Keseragaman kulit buat rambutan didominasi tipe tidak seragam sebanyak 20 tanaman. Pengamatan panjang rambut kulit buah rambutan terdapat empat tipe yaitu pendek, sedang, panjang dan sangat panjang. Panjang rambut kulit buah tanaman rambutan asal kabupaten Bengkalis didominasi tipe sedang sebanyak 13 tanaman.Tanaman rambutan asal Kabupaten Bengkalis memiliki warna aril yang terdapat tiga tipe yaitu putih, putih kusam dan putih krim. Warna aril buah rambutan asal Kabupaten Bengkalis didominasi tipe putih kusam 31 tanaman. Pengamatan tekstur aril tanaman rambutan terdapat tiga tipe yaitu lembut, keras dan renyah. Tekstur aril buah rambutan didominasi tipe renyah sebanyak 17 tanaman. Pengamatan ketebalan aril buah rambutan memiliki empat tipe yaitu tipis, sedang, tebal dan sangat tebal. Ketebalan aril buah rambutan yang terdapat didominasi tipis sebanyak 14 tanaman.

Tanaman rambutan asal Kabupaten Bengkalis pada padatan terlarut total buah rambutan memiliki empat tipe yaitu rendah, sedang, tinggi dan sangat tinggi. Padatan terlarut total buah rambutan didominsi rendah sebanyak 10 tanaman. Pengamatam rasa aril buah rambutan terdapat empat tipe yaitu hambar, asam, asam manis dan manis. Rasa aril buah rambutan didominasi asam manis 16 tanaman. Pengamatan pada kandungan air aril buah memiliki tiga tipe yaitu tidak berair, berair dan sangat berair. Kandungan air buah didominasi berair sebanyak 29 tanaman. Tekstur aril sangat berhubungan dengan adanya kandungan air. Aril lembut memiliki kandungan air banyak, sedangkan aril keras mempunyai kandungan air sedikit (Antarlina ,2009).

\section{Karakter Biji Tanaman Rambutan}

Hasil analisa data pada 31 tanaman rambutan di Kabupaten Bengkalis menunjukan nilai keragaman karakter biji tanaman rambutan berkisar 0,38 hingga 0,73. Dari perhitungan koefisien keragaman $(\mathrm{KK})$, nilai keragaman pada karakter panjang biji termasuk memiliki keragaman sedang. Sedangkan karakter lebar biji dan bentuk biji termasuk memiliki keragaman rendah. Keragaman karakter biji tanaman rambutan asal Kabupaten Bengkalis dapat dilihat pada Tabel 5.

Tabel 5. Data ragam dan Koefisien keragaman karakter biji 31 tanaman rambutan di Kabupaten Bengkalis.

\begin{tabular}{lccc}
\hline \multicolumn{1}{c}{ Karakter Biji } & Ragam & KK $(\%)$ & Keterangan \\
\hline Panjang biji & 0,73 & 27,86 & Sedang \\
Lebar biji & 0,38 & 23,55 & Rendah \\
Bentuk biji & 0,47 & 21,76 & Rendah \\
\hline
\end{tabular}

Tanaman rambutan asal kabupaten Bengkalis memiliki empat tipe panjang biji buah rambutan yaitu pendek, sedang, panjang dan sangat panjang. Panjang biji buah rambutan asal Kabupaten Bengkalis didominasi tipe panjang sebanyak 15 tanaman. Pengamatan tanaman rambutan pada karakter lebar biji terdapat empat tipe yaitu pendek, sedang, lebar dan sangat lebar. Lebar biji tanaman rambutan didominasi tipe lebar sebanyak 20 tanaman. Sedangkan pengamatan pada karater bentuk biji terdapat empat tipe yaitu roundist, obovoid, oboviod memanjang dan oblong. Bentuk biji tanaman didominasi oleh bentuk obovoid sebanyak 18 .

\section{Analisa Hubungan kerabatan Tanaman Rambutan}

Hubungan kekerabatan yang dianalisis dengan koefisien kesamaan menunjukkan kedekatan antar suatu aksesi dengan aksesi yang lain pada populasi rambutan di dareah penelitian ini. Hasil analisis hubungan kekerabatan 31 tanaman rambutan di Kabupaten Bengkalis disajikan pada Gambar 1. 


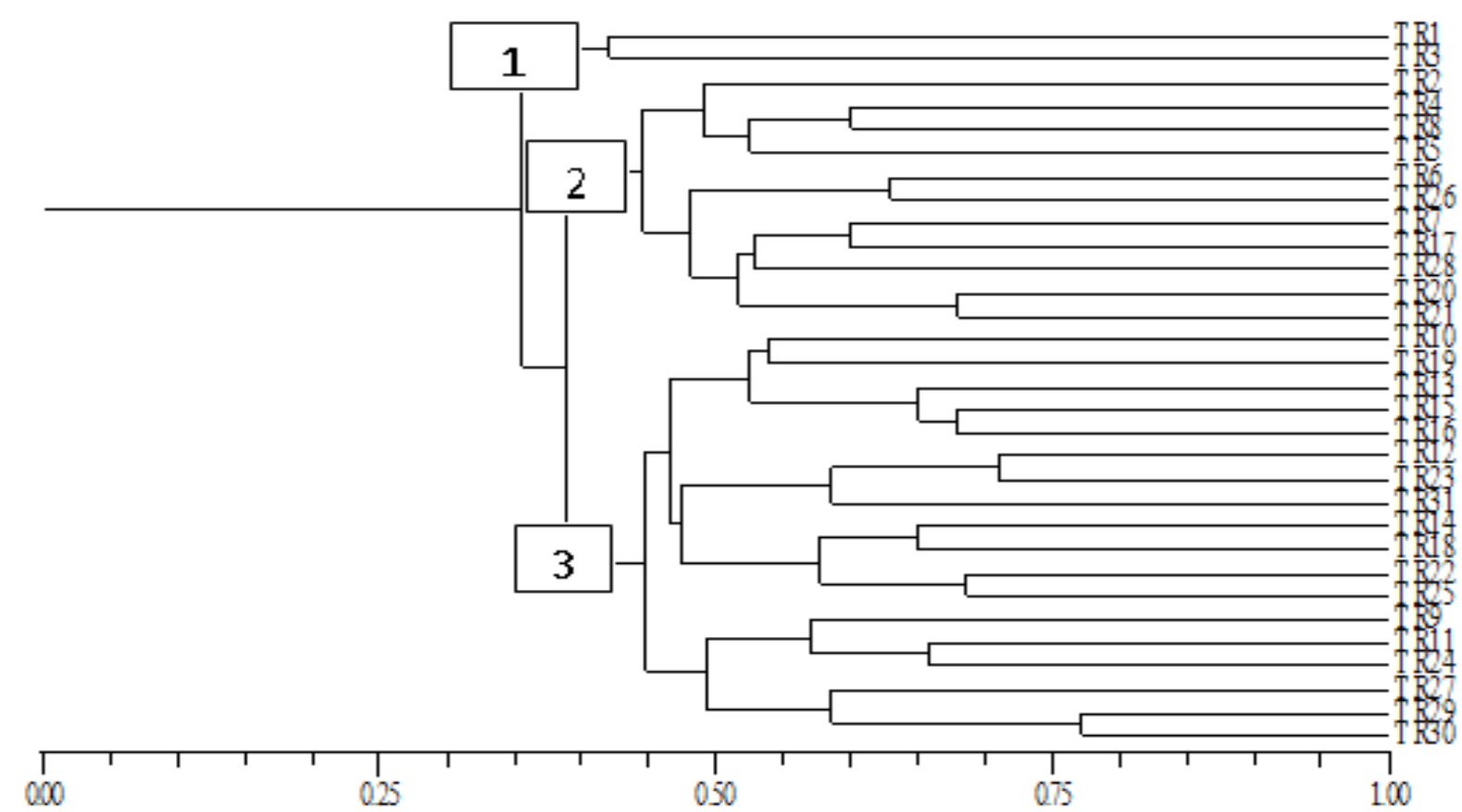

Gambar 1. Dendogram Hubungan Kekerabatan Tanaman Rambutan Kabupaten Bengkalis

Dendogram dari 31 tanaman rambutan di Kabupaten Bengkalis pada koefisien 0,40 terbentuk tiga kelompok utama. Kelompok satu terdiri dari 2 tanaman rambutan yaitu TR1 dan TR3 dengan nilai kemiripan 0,42 , dan memiliki kesamaan 18 karakter. kelompok dua terbagi menjadi dua subkelompok yaitu $2 \mathrm{~A}$ dan 2B, kelompok 2A terdiri TR2, TR4, TR8 dan TR5 dengan nilai kemiripan 0,49 dan memiliki kesamaan 8 karakter. Pada sub kelompok 2B yaitu TR6, TR26, TR7, TR17, TR28, TR20 dan TR21 dengan nilai kemiripan 0,48 dan memiliki kesamaan 4 karakter. Kelompok tiga terbagi menjadi dua sub kelompok yaitu $3 \mathrm{~A}$ dan 3B. Pada kelompok 3A yaitu TR10, TR19, TR13, TR15, TR16, TR12, TR23, TR31, TR14, TR18, TR22, dan TR25 dengan nilai kemiripan 0,47 dan memiliki kesaman 4 karakter, sedangkan kelompok 3B yaitu TR9, TR11, TR24, TR27, TR29 dan TR30 dengan nilai kemiripan 0,49 dan memiliki kesamaan 5 . Hubungan kekerabatan tanaman rambutan di Kabupaten Bengkalis yang sangat terdekat terdapat pada subkelompok 3B yaitu TR29 dan TR30 dengan nilai kemiripan 0,77. Kelompok tanaman ini memiliki hubungan kekerabatan yang sangat dekat berdasarkan karakter morfologi yang diamati terdapat karena memiliki kesamaan 27 karakter.

Hasil analisis kekerabatan berdasarkan kemiripan morfologi mampu memisahkan 31 individu tanaman rambutan di Kabupaten Bengkalis, akan tetapi pemisahan tidak berdasarkan asal tempat tumbuh tanaman rambutan. Pengelompokan tersebut menunjukan bahwa individu dari asal yang berlainan dapat tergabung dalam kelompok individu yang sama, sebaliknya individu yang berasal dari lokasi yang sama belum tentu tergabung dalam kelompok individu yang sama. Genotipe yang berasal dari daerah yang sama tidak selalu berada dalam klaster yang sama, artinya diversitas geografi tidak selalu ada hubungannya dengan diversitas genetik.. Persilangan antar aksesi yang memiliki jarak genetik yang jauh akan menghasilkan keragaman yang tinggi (Kuswandi et al., 2014).

\section{KESIMPULAN DAN SARAN}

\section{Kesimpulan}

Berdasarkan hasil penelitian yang telah dilakukan dapat disimpulkan bahwa Terdapat keragaman berdasarkan karakter morfologi pada tanaman rambutan di Kabupaten Bengkalis menjadi 3 kelompok yaitu rendah, sedang dan tinggi. Sedangkan hubungan kekerabatan tanaman rambutan di Kabupaten Bengkalis berdasarkan karakter morfologi terdapat 3 kelompok utama. lompok 1 terdiri dari 2 tanaman rambutan yaitu TR1 dan TR3. Kelompok 2 terbagi menjadi dua sub kelompok yaitu 2A dan 2B, Kelompok 2A terdiri dari 4 tanaman yaitu TR2, TR4, TR8 dan TR5. Pada sub kelompok 2B terdiri dari 7 tanaman yaitu TR6, TR26, TR7, TR17, TR28, TR20 dan TR21. Kelompok 3 terbagi menjadi 
dua sub kelompok yaitu 3A dan 3B. Pada kelompok 3A terdapat 12 tanaman yaitu TR10, TR19, TR13, TR15, TR16, TR12, TR23, TR31, TR14, TR18, TR22, dan TR25. Sedangkan pada kelompok 3B terdapat 6 tanaman yaitu TR9, TR11, TR24, TR27, TR29 dan TR30.

\section{Saran}

Plasma nutfah tanaman rambutan merupakan aset nasional yang perlu dilestarikan, oleh karena itu untuk mempertahankan plasma nutfah tanaman rambutan disarankan untuk melakukan eklporasi dan karakterisasi di daerah- daerah lain di Provinsi Riau.

\section{UCAPAN TERIMA KASIH}

Kepada Laboratorium Pemuliaan Tanaman Fakultas Pertanian Universitas Riau, Kampus Bina Widya km 12,5, Pekanbaru, yang telah membantu kelancaran pelaksanaan penelitian ini.

\section{DAFTAR PUSTAKA}

Antarlina, SS 2009. Identifikasi sifat fisik dan kimia buah buahan lokal Kalimantan. Jurnal Plasma Nutfah, 15(2):80-90.

Badan Pusat Statistik Provinsi Riau. 2017. Produksi Tanaman Buah. Pekanbaru.
Coleman, J.S., D.M. McConnaughay and D.D. Ackerly.1994. Interpreting phenotypic variation in plants. Tree. 9(5):187-191.

IPGRI. 2003. Descriptors for Rambutan (Nephelium lappaceum L.). Internasional Plant Genetic Resources Institute.Rome. Italy.

Kuswandi, Sobir, dan Suwarno. 2014. Keragaman genetik plasma nutfah rambutan di Indonesia berdasarkan karakter morfologi. Jurnal Hortikultura, 24(4):289-298

Makarim, AK dan E. Suhartatik 2006. Budidaya Padi Dengan Masukan In Situ Menuju Perpadian Masa Depan. Jurnal Iptek Tanaman Pangan, 1(1):19-29.

Miswarti, E.P. Wawan dan D.Sugandi 2017. Analisis keragaman plasma nutfah durian di Provinsi Bengkulu berdasarkan karakter morfologi. Jurnal Plasma Nutfah, 23(1): 59-68.

Pornomo, S. 1987. Eksplorasi mangga liar di Kalimantan. Jurnal Hortikultura, 5(2):126.

Raharjo J.T. dan R.Sadono 2008. Model tajuk jati (Tectona grandis L.F) dari berbagai suku pada uji keturunan umur 9 tahun. Jurnal Ilmu Kehutanan, 2(2):89-95. 